\title{
Universities and Education
}

$\mathrm{T}$ HE discussion in Section G (Engineering) of the British Association at Nottingham on September 3 on the training of university graduates for the engineering industry, which was opened by Prof. F. G. Baily, was notable not only for the high level sustained, apart from one or two lapses, but also for some stimulating remarks on the functions and character of university training in general which merit the attention of a wider audience.

In his introductory paper, Prof. Baily reviewed the scope and subject-matter of the various courses at present followed, and urged that for most men the practical training should follow the college course. $\mathrm{He}$ does not consider that the theory of commerce or industry should be included in the three-year curriculum, but should preferably be studied after some practical experience has been acquired. It is also doubtful whether a fourth year of study repays all students for the time spent. Prolonged study of theory may be of slight benefit to students of medium capacity and of little use in several branches of employment. Prof. Baily also stressed the value of the sandwich system and the perspective which some manual training gives as well as the closer contact with the workmen. The latter, rather than the acquisition of manual skill, are the most valuable results of manual training.

Dr. W. Jackson, who presented a joint paper with Dr. A. P. M. Fleming, stressed the need for a more effective co-ordination of the resources of the universities and of industry. The task of educating and training for engineering careers those who will ultimately occupy positions of high technical and administrative responsibility is a joint responsibility between the universities and industry, and Dr. Fleming and Dr. Jackson pleaded for a broader interpretation of industry's share in this responsibility. They made the somewhat revolutionary suggestion that the large industrial organizations should accept the responsibility of training such men for the country as a whole, and that the smaller concerns should no longer recruit direct from the universities. The tendency to include industrial administration and an increasing amount of specialized technological information in university courses was again adversely criticized, Dr. Jackson pointing out that this overloading or undue specialization is detrimental to their educational value. Opportunities for independent reading and thinking, and the exereise of originality, may be unduly restricted, and too high a premium placed on memory and the ability to reproduce information in the exact form in which it has been communicated in the lecture. The undergraduate stage is much too early a stage at which to encourage intensive specialization.

Dr. Fleming and Dr. Jackson suggested that the universities might now reasonably expect the large industrial firms to undertake, both independently and in co-operation with adjacent technical colleges, the necessary systematic instruction in the specialized branches of engineering technology with which they are concerned. If facilities for combined practical and technological training could be made available on a wide scale, the opportunity for a liberal education at the university and the effectiveness of the overall training could be increased considerably. Moreover, if released from technological obligations, the universities could do much to stimulate in the embryo engineer the development of broader interests and participation in wider fields of activity. If engineers are to make their full contribution to the solution of the complex problems of modern life, their interests cannot be limited to technical matters, and the opportunities for humane studies and for participation in the corporate life of the university are two of the most important attributes of a university education.

Finally, Dr. Fleming and his colleague, referring to the universities and industrial research, urged that men of outstanding ability should be given the opportunity to return for one or two years to an appropriate university, either at home or abroad, to learn more effectively the method and art of research and to enhance their fundamental scientific knowledge. A regular stream of such men from industry, endowed by adequate joint scholarship provision, would exercise a very stimulating effect on the research and teaching activities of the universities. In addition, the engineering departments of the universities have an excellent opportunity for cooperative research with the physics, chemistry and metallurgical departments on borderline subjects in which industry is keenly interested but which an in. dustrial research laboratory may be unable to tackle. Industry should also afford facilities in its research laboratories for members of university staffs to carry out or supervise supplementary work beyond the scope of their financial resources, thus assisting them to keep in touch with outstanding industrial problems.

Many of the points made in these two papers were strongly endorsed in the discussion which followed. In a written communication describing the training of engineer recruits for the Post Office service, Sir George Lee referred to the stress laid on personality, judgment and character in candidates rather than on technical knowledge, and emphasized the importance of a wider cultural education with, if possible, two foreign languages. A general education which equips the engineer to take some part in everyday affairs is much to be preferred to the present overspecialized education.

Mr. S. V. Goodall, who dealt with the Admiralty system of recruitment and training for the Royal Corps of Naval Constructors, referred particularly to the Admiralty's efforts to obtain university graduates who have not had any experience in shipyard work but have attained a high standard in mathematics and naval construction.

Sir T. Hudson Beare, after emphasizing the value of instruction in design as affording a means for expressing creative ability, asserted that the fundamental task of the university is to turn out trained minds able to absorb knowledge readily later on in life when left to their own resources, and to take their proper place in the life of the nation. The only specialization at a university should be specialization in the fundamental principles of the science. Mr. H. A. Ward, of Messrs. Rolls-Royce, Ltd., described a recent experiment in the employment of university graduates which is giving promising results, and Prof. C. H. Bulleid endorsed a number of Prof. Baily's and Sir Hudson Beare's remarks regarding premature specialization and the place of university training. Prof. E. W. Marchant also strongly endorsed the value of a university training for an engineer, 
stressing particularly the importance of association with other students, and paid tribute to the work done by Dr. Fleming to encourage the employment of university graduates in industry.

Other speakers in the discussion reiterated the importance of concentration upon fundamental principles and humanitarian studies in a university training, while in regard to research it was pointed out that the greater expensiveness of engineering research, as compared with research in the physical sciences, is often a great handicap to the universities in initiating such work. Prof. R. V. Southwell suggested that the time is ripe for a drastic revision of engineering curricula, and a further speaker urged an inquiry into the whole question of scientific education, with the view, among other things, of eliminating the overlapping which at present exists between the technical schools and colleges and the universities.

The educational functions of the university were also touched upon from a different aspect in discussions before Section I (Educational Science). Incidental reference was made to the part of the university in the discussion on education for the community on September 3, although Prof. A. M. Carr-Saunders did not present his paper on this subject. A special session on September 6 was, however, devoted to the educational function of the university. Sir Richard Livingstone, who opened the discussion, took as his main theme the need for a new type of adult education which the universities are pre-eminently qualified to impart.

If the university sends out graduates with a thorough mental training and a background, it has done what it can to prepare them for life. When, however, education ceases at the age of twenty-two or twenty-three years, in our swiftly changing world a man is very liable to lose intellectual energy by the time he is forty and fail to keep up with advancing knowledge. Sir Richard urged that everyone engaged in routine or practical work, especially if he occupies a directing or controlling position, needs periods of systematic study to refresh, re-equip and re-orientate his mind. There is no occupation or profession in which the resumption of systematic education in later life would not be profitable, and there are fow who would not greatly profit by it. Already in medicine and in teaching, refresher or vacation courses are being arranged, and Sir Richard referred to experiments in the same direction in civil and local government service. The Commonwealth Fund awards three fellowships for study in the United States to eivil servants to enable them to carry out inquiry or research on problems akin to those which come within the scope of the Department in which they are serving. A summer sehool in colonial administra. tion has been organized by the University of Oxford with the encouragement and help of the Colonial Office and Colonial Governments, in which detailed problems of native administration are placed in a wide general and comparative setting. A third instance is the growing practi $\ni$ of granting officers leave for part-time study in such courses as the diploma course in public adm nistration at Oxford.

This type of adult educatic 1, which enables the student to place his special suk ect against the background of modern civilizatior can only be supplied by the universities, and an extension of the practice of seconding promising officials for systematic study at the university would do much to break down the dangers which routine continually threatens. Moreover, this practice would tend to remedy the serious neglect of the social sciences. Bringing back to the university in this way the civil or municipal servant, the medical or other professional man and the business man, with the first-hand knowledge of social conditions which they possess, would not only add to the data on which the social sciences depend and stimulate the cross-fertilization of theory and practice which is such a fruitful source of advance, but also assist to prevent disastrous mistakes in the study of these sciences, which aim at directing the policy of Govern. ments and the conduct of millions of human beings.

The functions of the universities in regard to the social sciences were discussed in still greater detail by Prof. M. Ginsberg, who condemned the divorce of the teaching of the social sciences from that of social philosophy. This separation is the more unfortunate because the problems of deepest interest to layman and student alike are those in which questions of value and questions of fact are closely interwoven, and to see them in their proper relation is of the most vital importance. The training at present provided in the universities is not well calculated to achieve this object, for students, while trained in marshalling and correlating facts, have no parallel experience in weighing values or in disentangling values in complex social situations. Social science has two functions to fulfil, both of special relevance and urgency at the present time. The first, or critical function, is concerned with the presuppositions or assumptions underlying commonsense and scientific thought about social phenomena and with the nature and validity of the methods employed in investigating them. It is urgently necessary that philosophy should attempt to provide a critical apparatus for scrutinizing and evaluating the methods and assumptions made by the social sciences, and particularly the fundamental conceptions from which a synthesis of the social sciences may proceed. A philosophical analysis of the conceptions of social change, which are in fact employed, for example, in the different social sciences, would greatly help in clarifying the present confusion. Similarly, the philosopher could do much to guard against confusions which may arise out of misunderstandings regarding the logical character of the laws and the relations between necessity, freedom and law. The relation between purely deductive studies and the more concrete or inductive handling of economic data also requires elucidation.

That function of social philosophy which is concerned with the problem of values is, however, of even greater importance to-day and Prof. Ginsberg considers that in economic questions the moral issues involved at present most urgently require clarification. In many cases our moral judgments of particular institutions would be transformed if we had fuller knowledge of the ends actually attained in relation to the ends they are intended to serve. The effective handling of social problems involves a synthesis, but not a fusion of social science and social philosophy, and co-operation is even more important in the teaching of political science and especially of international relations. The present neglect of philosophy is due partly to the little attention devoted to social problems by philosophers, and particularly to the failure to bring the teaching of ethics into relation with present needs. Prof. Ginsberg considers that great changes are required in the teaching of both social science and social philosophy if the universities are to make their rightful contribution towards the rational ordering of society. 